\title{
純アルミニウム焼なまし板の機械的性質の異方性
}

\author{
佐久間 尚幸* . 村松 俊樹* . 田尻 彰* . 関田 宗太郎*
}

Journal of Japan Institute of Light Metals, Vol. 55, No. 6 (2005), pp. 245-251

\section{Anisotropy of mechanical properties in annealed pure aluminum sheets}

\author{
Takayuki SAKUMA*, Toshiki MURAMATSU*, Akira TAJIRI* and Soutaro SEKITA*
}

\begin{abstract}
Anisotropy of mechanical properties in full annealed sheets was studied using pure aluminum with $\{100\}\langle 001\rangle$. Yield stress anisotropy was not observed. However, work hardening behavior, flow stress and several kinds of elongation were different depending on tensile direction. The anisotropic behavior in fracture elongation was well consistent with that in uniform elongation. Namely, the elongation was maximum at a direction of $45^{\circ}$ to $\mathrm{RD}$. In contrast, elongation parallel to $\mathrm{RD}$ exhibited the minimum value. The anisotropy of the uniform elongation was due to anisotropic behavior of the work hardening. Crystallographic orientation and dislocation structure developed by tensile deformation played an important role in the anisotropy of these properties.
\end{abstract}

(Received August 17, 2004)

Keywords: anisotropy, mechanical properties, pure aluminum, crystallographic orientation, dislocation structure

\section{1. 緒言}

被加工材の材料特性，加工方法および加工時の潤滑条件な ご，様々な要因が成形性に影響1）を及ぼすため，これら諸条 件を適切に制御することが成形性の向上につながる。用途に よっても異なるが，一般的には $\mathrm{n}$ 值や $\mathrm{r}$ 值，更に伸びの大き いことが被加工材に求められる基本的な材料特性である。そ のうえ, これら材料特性は等方的であること, 言い換えれば, 何れの方向であ同じような材料特性であることが求められて いる。

しかし，ときには異方性を利用することで，特定方向の材 料特性だけを向上させることも必要であると考えられる。し たがって，それぞれの材料特性の異方性発生メカニズムを明 らかにしておけば，用途に合せて等方的な材料特性になるよ ううまく異方性を制御したり, 逆に異方性を大きく発達させ ることで特定方向の材料特性を向上させたりすることも期待 できる。

一般に，材料特性の異方性には集合組織がかかわってい る2)ことが広く知られている。しかし，実際には集合組織だ

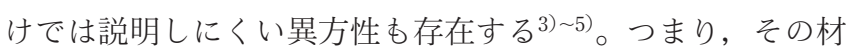
料特性に対して支配的な金属学的因子が異方性に影響するも のと考えられる。

たとえば, 圧延材の降伏応力は転位密度之密接に関係して いる。更に, 転位密度は転位セルサイズとも関係があり, そ のサイズが小さいほど転位密度は高い。そのうえ, セルを取 り囲んでいる高密度な転位セル壁むあり, これらはすべり変 形への抵抗となる。加工履歴や組織要因の影響を強く受けて 転位組織は形成されるため, 転位セル壁には必然的に配列の 異方性が発達する。したがって, 加工組織を含む圧延材の降
伏応力に異方性が現れる ${ }^{3)}$ 。

以上のようなことから，金属材料の優れた特性を最大限に 引出すには, 様々な材料特性の異方性発生メカニズムを明ら かにして，その異方性に対して支配的な要因を制御すること が必要であると考えられる。本研究では様々な材料特性の異 方性の中から, 焼なまし板の機械的性質の異方性発生メカ二 ズムを検討した。

\section{2. 実験方法}

\section{1 試料と加工熱処理}

硬化に寄与するような析出物，伸びを低下させるような粗 大な晶出物は加工熱処理の履歴によって分散状態に異方性が 現れる。更に，その異方性は機械的性質の異方性に影響を及 ぼす可能性も考えられる。そこで, これらの影響をできるだ け少なくするため，供試材には純アルミニウムを用いた。

Table 1 に試料の化学成分を示す。

結晶方位によって焼なまし材の機械的性質は異なる ${ }^{6)}$ が, 異方性発生のメカニズムについて更に詳しく検討する必要が ある。そこで, 結晶方位が比較的単純な Cube 方位, すなわ ち $\{100\}\langle 001\rangle$ が主方位として発達するような焼なまし材を 作製するため, 加工熱処理の制御を行い, 機械的性質の異方 性発生メカニズムを整理した。Table 2 に供試材の加工熱処 理条件を, Table 3 に最終焼なまし板の特徵を要約した。

Table 1 Chemical composition (mass \%) of specimens

\begin{tabular}{c|c|c}
\hline \hline Fe & $\mathrm{Si}$ & $\mathrm{Al}$ \\
\hline 0.11 & 0.04 & bal. \\
\hline
\end{tabular}

\footnotetext{
*古河スカイ(森（† 366-8511＼cjkstart埼玉県深谷市上野台 1351）。Furukawa sky Co., Ltd.（1351 Uwanodai, Fukaya-shi, Saitama 366-8511).

E-mail: sakuma.takayuki@furukawa-sky.co.jp
} 
Table 2 Thermomechanical treatments of specimens

\begin{tabular}{l|l}
\hline \hline Pre-heating & $753 \mathrm{~K}-7.2 \mathrm{ks}$ \\
Hot rolling & $70 \rightarrow 4(\mathrm{~mm})$ \\
Cold rolling & $4 \rightarrow 2(\mathrm{~mm})$ \\
Intermediate annealing (in salt bath) & $723 \mathrm{~K}-38 \mathrm{~s}$ \\
Cold rolling & $2 \rightarrow 0.4(\mathrm{~mm})$ \\
Final annealing (in salt bath) & $723 \mathrm{~K}-16 \mathrm{~s}$ \\
\hline
\end{tabular}

Table 3 Characteristics in final annealed sheets

\begin{tabular}{l|l}
\hline \hline Grain structure & equiaxed \\
Coarse particle & few \\
Precipitation contributing to hardening & none \\
Texture & $\{100\}\langle 001\rangle$ \\
\hline
\end{tabular}

\section{2 引張試験と加工硬化率の計算}

最終焼なまし板から压延方向に対して $0,45,90^{\circ}$ 方向に試料 を切出し, JIS5 号試験片を作成して初期ひずみ速度 $6.67 \times 10^{-3} \mathrm{~s}^{-1}$ で各方向 3 本ずつ引張試験を行った。加工硬化 率 $(\delta \sigma / \delta \varepsilon)^{7)}$ は引張試験で得られた公称応力 - 公称ひずみ曲 線を真応力 - 真ひずみ曲線に変換し, 引張変形時のひずみ変 化量 $(\delta \varepsilon, \delta \varepsilon=0.005)$ に対する流動応力の变化量 $(\delta \sigma)$ を求 め, 真ひずみ 0.01 から計算した。な押, 塑性不安定が生じる ような条件下 $(\sigma \geqq(\delta \sigma / \delta \varepsilon))$ では真応力 - 真ひずみ曲線に 変換できないため, $\sigma<(\delta \sigma / \delta \varepsilon)$ が成立する条件まで加工硬 化率を計算した。

\section{3 集合組織測定}

最終焼なまし材と引張变形を施した材料の板表面で, $\{100\},\{110\},\{111\}$ の不完全極点図 $\left(\alpha=15 \sim 90^{\circ}\right)$ をX 線回 折にて測定した。引張方向は压延方向に対して $0,45^{\circ}$ 方向で, 公称ひずみ $5 \sim 25 \%$ まで变形を加えた。 $45^{\circ}$ 方向に变形を加え た試料は, 引張方向を従来の $\mathrm{RD}$ 軸に置き換えて X 線回折を 行った。また, 級数展開法にて展開次数 22 次まで計算し, 方位分布関数 (ODF) を作成した。

\section{4 組織観察}

光学顕微鏡 $(\mathrm{OM})$ と走査型電子顕微鏡（SEM）を用い, 最終焼なまし板の圧延方向断面（ND-RD 断面）で再結晶粒 組織と晶出物の分布を観察した。再結晶粒径は ND-RD 断面 で撮影した組織写真を利用し，引張軸に対して $45^{\circ}$ の方向に 直線を描き切断法にて求めた。また, 画像解析処理装置, ルーゼックスを用いて最大径 $1 \mu \mathrm{m}$ 以上の晶出物の面積率を 測定した。

引張变形による転位組織变化は透過電子顕微鏡（TEM）を 用いて観察した。引張方向は圧延方向に対して $0^{\circ}$ 方向で, 公 称ひずみ $5 \sim 25 \%$ まで変形させた。

\section{3. 実験結果と考察}

\section{1 最終焼なまし板の顕微鏡組織}

Fig. 1 に最終焼なまし板の再結晶粒組織と晶出物の分布を 示す。結晶粒の形状は，ほぼ等軸状であった。結晶粒の平均 サイズは $38 \mu \mathrm{m}$ であったが，小さな結晶粒は約 $10 \mu \mathrm{m} ，$ 逆に 大きなあのでは約 $60 \mu \mathrm{m}$ の結晶粒があり，比較的小さな結晶 粒と大きめの結晶粒が混在している。

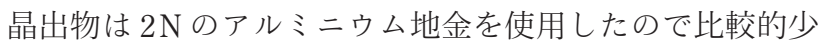

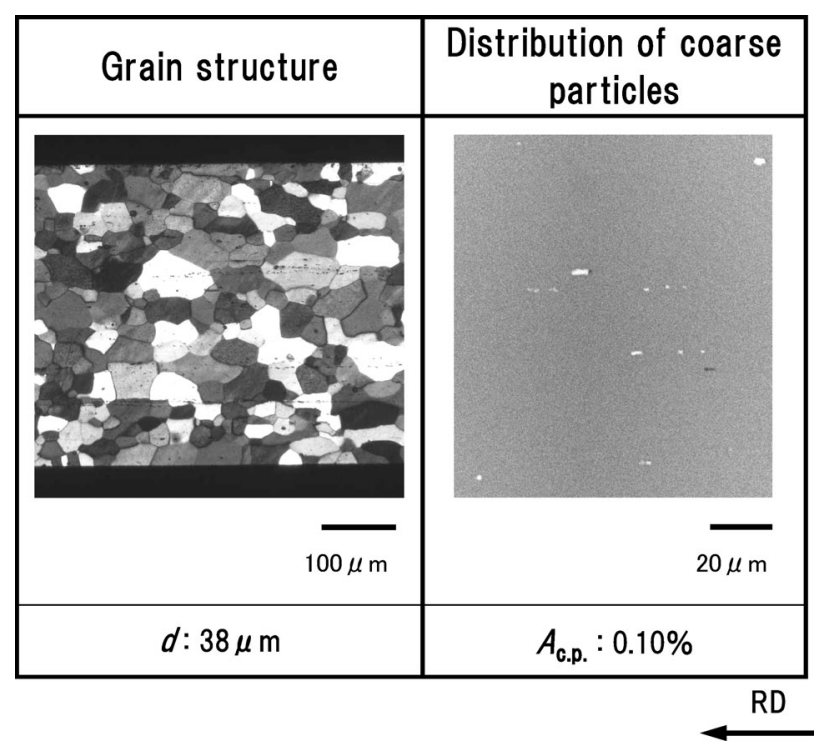

Fig. 1 Grain structure and distribution of coarse particles in longitudinal section of final annealed sheet. Mean grain size $(d)$ and area fraction of coarse particles $\left(A_{\text {c.p. }}\right)$ larger than $1 \mu \mathrm{m}$ are also shown in columns under micrographs.

ない。写真上で白く見える $\mathrm{Al}-\mathrm{Fe}(-\mathrm{Si})$ 系の晶出物の占める 割合が面積率で $0.10 \%$ 程度だった。また, 晶出物は圧延方向 に連なって分布していることがわかる。更に, 圧延面に平行 な面で組織を観察した場合でも, 晶出物は圧延方向に連なっ て分布していた。

\section{2 応力ーひずみ曲線の異方性}

Fig. 2 は最終焼なまし板から压延方向に対して $0,45,90^{\circ}$ 方 向に試験片を切出し, 引張試験した公称応力ー公称ひずみ曲 線を示す。さらに, 降伏応力, 引張強さ, 伸びの平均值と誤 差を Table 4 にまとめた。な押, Fig. 2 の公称応力ー公称ひ ずみ曲線は各引張方向の中で破断伸びが最も大きかったもの を取り上げた。

降伏応力は 3 方向とも同じ值を示したが，加工硬化挙動や 流動応力, さらに伸びの大きさは引張方向によって大きく異 なった。すなわち，3方向の中では $45^{\circ}$ 方向の加工硬化が全 体的に大きい。したがって，0,90方向に比べ $45^{\circ}$ 方向の流 動応力が全体に高い。また, 破断伸びは $45^{\circ}$ 方向が最も大き く, $0^{\circ}$ 方向が小さい。破断伸びを一様伸びと局部伸びに分類 し異方性への影響を検討したところ, 破断伸びと同じ挙動が 一様伸びに認められた。つまり, 一様伸びも $45^{\circ}$ 方向が大き く, $0^{\circ}$ 方向が小さい。これに対し, 局部伸びは一様伸びや破 断伸びと異なる挙動で $45^{\circ}$ 方向が最む小さい。さらに，異方 性の指標として, 3 方向の中での各機械的特性の最大值と最 小值の差を Table 4 中に記載したが, 破断伸びの異方性は $6.6 \%$ ，一様伸びの異方性は $7.8 \%$ ，局部伸びの異方性は $2.5 \%$ であり，一様伸びの方が局部伸びょりも異方性が大きい。以 上のことから，一様伸びの異方性が破断伸びの異方性に影響 を及ぼしていることが理解できる。

\section{3 加工硬化率の異方性と伸びの異方性}

Fig. 3 では圧延方向に対して $0,45,90^{\circ}$ 方向に引張試験した 場合の真応力と加工硬化率の関係を整理した。3 方向とも流 動応力の增加に伴い加工硬化率は低下したが, その低下量に は異方性がある。変形初期では $0^{\circ}$ 方向の加工硬化率が最も 
Table 4 Yield stress, tensile strength and several kinds of elongation in final annealed sheets

\begin{tabular}{c|c|c|c|c|c}
\hline \hline Tensile direction & YS (MPa) & TS (MPa) & F.EL. (\%) & U.EL. (\%) & P.U.EL. (\%) \\
\hline $0^{\circ}$ & $25_{-1}^{+0}$ & $68_{-1}^{+0}$ & $43.5_{-0.8}^{+1.3}$ & $30.9_{-0.8}^{+0.8}$ & $12.6 \pm 0.5$ \\
\hline $45^{\circ}$ & $25 \pm 0$ & $71_{-0}^{+1}$ & $50.1_{-1.5}^{+1.1}$ & $38.7_{-0.7}^{+0.7}$ & $11.4_{-0.9}^{+0.5}$ \\
\hline $90^{\circ}$ & $25 \pm 0$ & $65 \pm 1$ & $45.7 \pm 1.4$ & $31.8_{-1.0}^{+0.9}$ & $13.9+0.5$ \\
\hline Anisotropy & 0 & 6 & 6.6 & 7.8 & 2.5 \\
\hline
\end{tabular}

Anisotropy: Max value-Min value

F.EL.: Fracture Elongation

U.EL.: Uniform Elongation

P.U.EL.: Post-Uniform Elongation

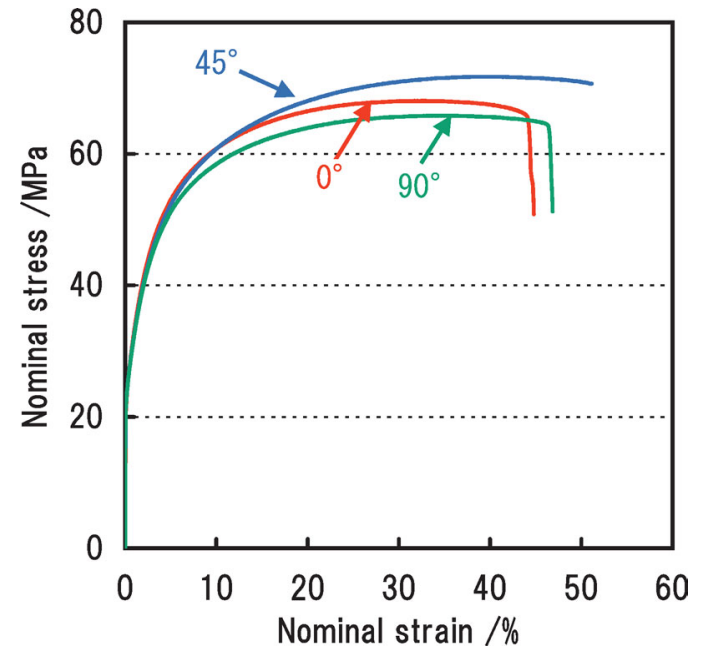

Fig. 2 Nominal stress-nominal strain curves at different tensile directions of final annealed sheet. Tensile directions were 0,45 and $90^{\circ}$ to $\mathrm{RD}$.

高い值を示し，45, 90方向はほぼ同じであった。しかし，流 動応力が約 $50 \mathrm{MPa}$ を超えると $45^{\circ}$ 方向の加工硬化率が最む 高くなった。さらに, 塑性不安定が開始する流動応力 $(\sigma=(\delta \sigma / \delta \varepsilon))$ に近づくと, $0^{\circ}$ 方向の加工硬化率は $90^{\circ}$ 方向 とほぼ等しくなった。つまり, 塑性不安定が開始する前まで の加工硬化率の低下量は $45^{\circ}$ 方向が少なく, $0^{\circ}$ 方向が多い。 この加工硬化率の挙動から伸び異方性について以下のような 推察を行った。

流動応力が増加するときには何れの方向でむ加工硬化率は 低下するが，その低下量が少ないとき，すなわち加工硬化能 の低下が小さい場合には一様伸びが大きくなる。さらに，局 部伸びょりも一様伸びの方が破断伸びに占める割合が大きい ので, 一様伸びが大きいと破断伸びも相対的に大きくなる。 したがって，450方向の破断伸びが最も大きくなり，逆に $0^{\circ}$ 方向が小さくなったと考えられる。

\section{4 加工硬化率の異方性に影響を及ぼす因子}

(1)結晶粒径, (2)析出物, (3)晶出物, (4)転位組織, (5)結晶方 位など種々の金属学的因子が加工硬化率の異方性に影響を及

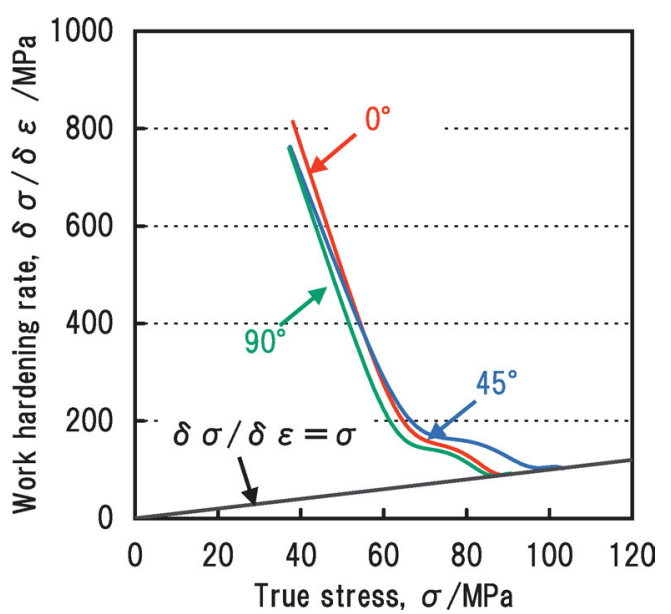

Fig. 3 Relations between true stress and work hardening rate at 0,45 and $90^{\circ}$ to $R D$.

ぼす可能性が考えられるため, これらの中で加工硬化率の異 方性を発達させる因子を検討した。

(1)結晶粒径の影響

引張变形前の初期結晶粒が大きいと加工硬化能は小さくな る ${ }^{8)}$ 。したがって, 結晶粒の大きさによって加工硬化率は異 なる。今回の実験で用いた供試材の場合, 結晶粒の大きさは 10 60 $\mu \mathrm{m}$ で, 結晶粒の大きさには不均一性がある。つまり, 結晶粒の大きさがそれぞれ異なるため, 加工硬化率も結晶粒 の大きさごとに異なる可能性が考えられる。しかし，引張試 験前の結晶粒の形状は等軸状であったので, 引張方向を変え た場合でも 3 方向とも同じような加工硬化率の挙動になるこ とが考えられる。したがって, 加工硬化率に異方性は現れに くいと考えられる。

\section{(2)析出物の影響}

今回の実験では析出物の同定をしていないが，供試材の化 学成分などから考慮すると, $\mathrm{Al}-\mathrm{Fe}(-\mathrm{Si})$ 系や単体 $\mathrm{Si}$ の析出 物などが母相中に存在しているものと考えられる。このよう な析出物は析出硬化には寄与しないので, 加工硬化率に影響 を及ぼす可能性は小さく，その異方性にも大きく寄与しない と考えられる。 


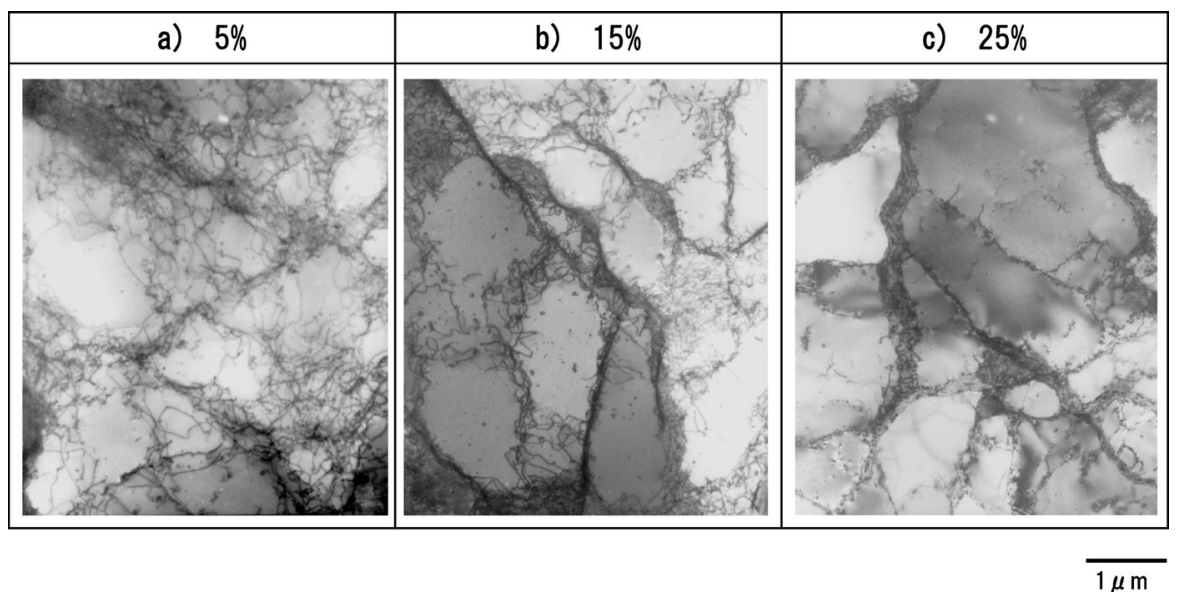

Fig. 4 Change in dislocation structure by tensile deformation. Nominal strain was 5,15 , and $25 \%$. Tensile direction was parallel to RD.

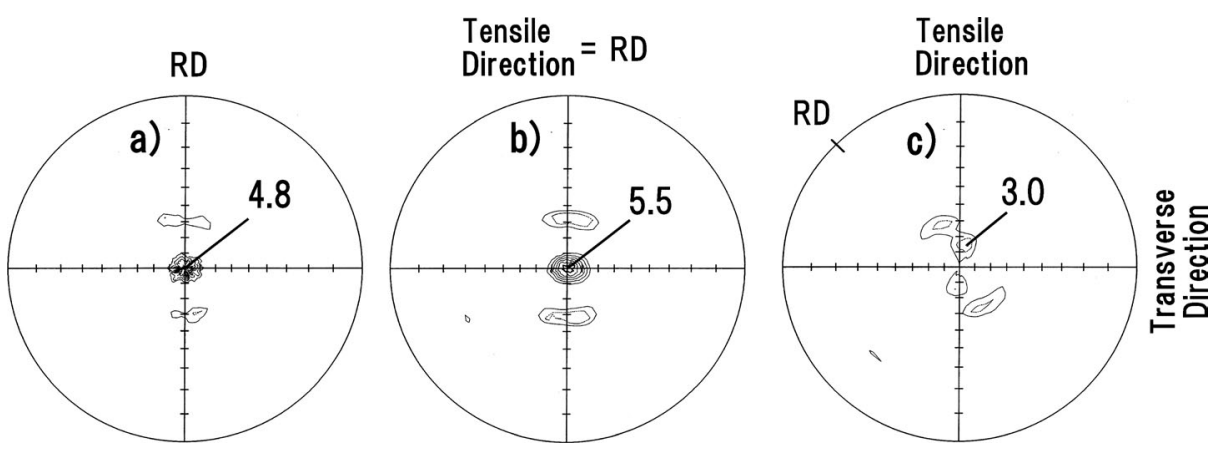

Fig. $5\{100\}$ pole figures before and after tensile deformation.

a): before deformation

b): after $15 \%$ deformation at $0^{\circ}$ to $\mathrm{RD}$

c): after $15 \%$ deformation at $45^{\circ}$ to $\mathrm{RD}$

\section{(3)晶出物の影響}

供試材には合金元素を添加しなかったが，不純物元素の $\mathrm{Fe}$ および Siがわずかに含まれていたので， $\mathrm{Al}-\mathrm{Fe}(-\mathrm{Si})$ 系の晶 出物が面積率で $0.10 \%$ 存在していた。また，これら晶出物は 圧延方向に沿って配列する傾向が認められた。したがって, この晶出物の配列異方性が加工硬化率の異方性に影響を及ぼ す可能性む考えられる。しかし, 晶出物の占める割合が少な いので，加工硬化率には大きく影響しないと考えられる。

(4)転位組織の影響

Fig. 4 に公称ひずみ $5,15,25 \%$ （真ひずみ $0.05,0.14,0.22 ）$ ま で引張変形を加えた試料の転位組織を示す。引張方向は圧延 方向に対して 0 方向である。变形量が $5 \%$ （真応力： $56 \mathrm{MPa）}$ では絡み合ったままの転位線が密集しているが，すでに一部 の領域ではセル化の傾向が認められた。観察した限りでは, セル化した領域よりも転位線が絡み合った領域の方が多いよ うに見えた。特に, 転位線の絡み合った領域は, 結晶粒界の 近傍より結晶粒内の方が多いような傾向であった。つまり, 転位組織には場所的な不均一性があるが，5\%の変形量では すでに動的回復が始まりつつある。

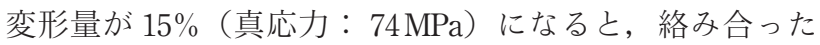
転位線の領域よりあセル化している領域の方が目立つように なった。すなわち, 変形量が $5 \%$ のときより屯動的回復が進

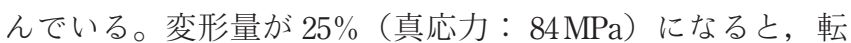

位組織は完全にセル化していた。また，セルの大きさは場所 的に不均一であるが, 变形量が大きくなるにつれセルサイズ は小さくなる傾向であった。

動的回復が進むと加工硬化能は低下するので，転位組織の 影響が加工硬化速度の異方性を発達させる可能性が考えられ る。また，転位組織と結晶方位とは密接な関係がある。たと えば, Cube 方位粒は他方位粒に比べて变形によるひずみの蓄 積が少ないことが報告されている ${ }^{9)}$ 。つまり, 結晶方位によっ て，ひずみを蓄積しやすい方位と蓄積しにくい方位がある。 したがって，転位組織と結晶方位とのつながりを明らかにす れば，加工硬化速度の異方性発生メカニズムも整理できると 考えられるので, 結晶方位の影響についても検討した。

\section{(5)結晶方位の影響}

Fig. 5 a）は引張变形前の $\{100\}$ 極点図を，b), c）は圧延 方向に対して $0,45^{\circ}$ 方向に公称ひずみ $15 \%$ まで引張变形を施 した後の $\{100\}$ 極点図を示す。引張变形前では最大 $4.8 \times \mathrm{ran}-$ dom の集積度であったが， $0^{\circ}$ 方向に引張变形を加えた場合に は $5.5 \times$ random まで集積度が上がった。一方， $45^{\circ}$ 方向に引張 変形を施した場合には，3.0×random まで集積度は低下した。 さらに, 板幅方向（TD 軸）迴りに結晶方位が回転したため, 極点図の中心にあった（100）が Tensile Direction 軸の方へ約 $13^{\circ}$ 回転した。

Fig. 6 a）に圧延方向に対して $0^{\circ}$ 方向に引張变形を施す前 
a)

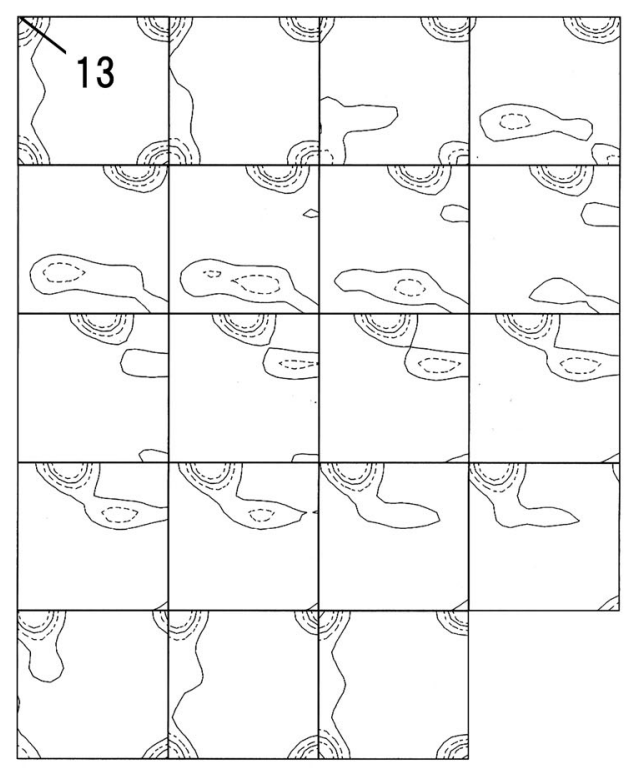

b)

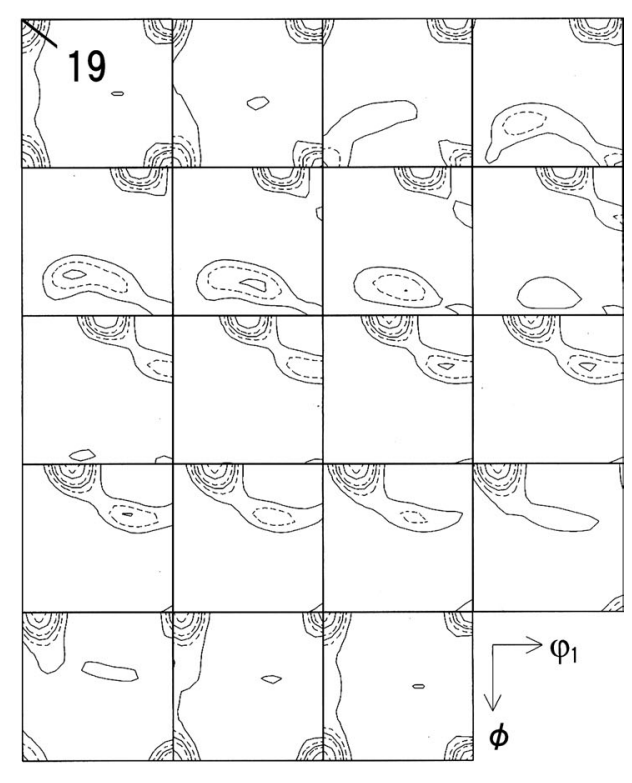

Levels: $2,4,6,8,12,16$

Fig. 6 Orientation distribution functions before and after tensile deformation at $0^{\circ}$ to RD.

a): before deformation

b): after $15 \%$ deformation
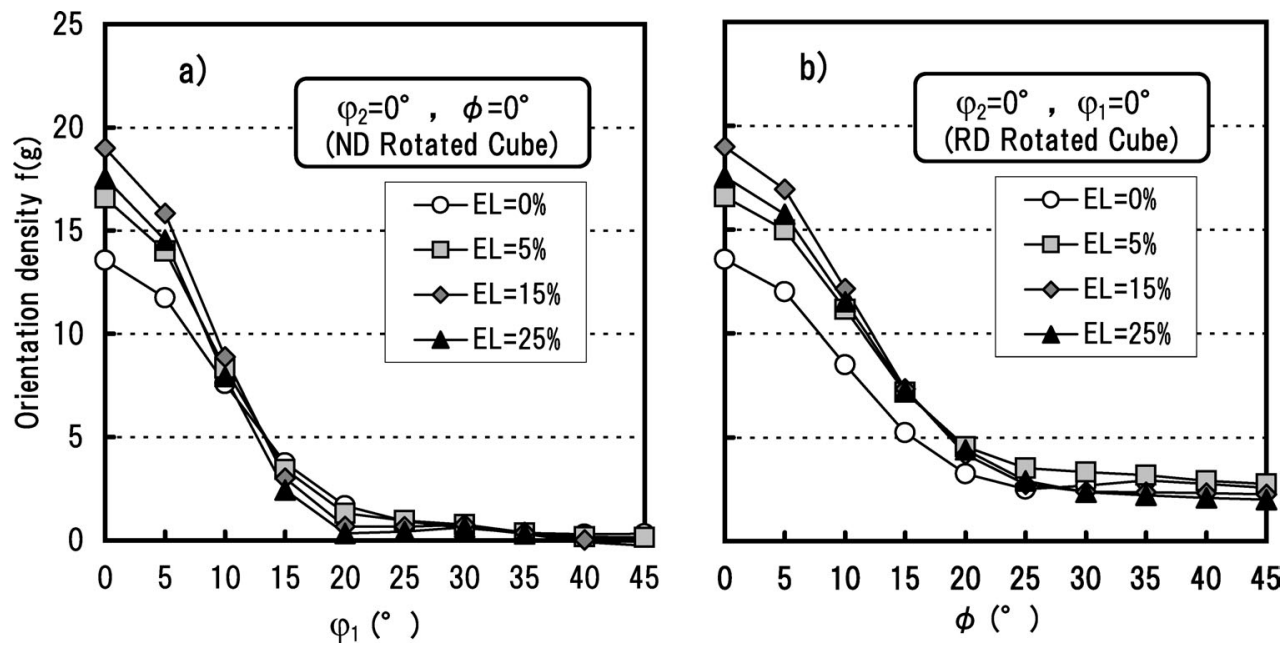

Fig. 7 Change in orientation density of $\varphi_{2}=0^{\circ}$ section by tensile deformation at $0^{\circ}$ to RD. a): $\phi=0^{\circ} \quad \varphi_{1}=0 \sim 45^{\circ}$ b): $\varphi_{1}=0^{\circ} \quad \phi=0 \sim 45^{\circ}$

の ODF を，b）は $15 \%$ まで引張変形を施した後の ODF を示 す。変形前後で大きく变化した結晶方位は $\varphi_{2}=0^{\circ}$ 断面から明 らかなように，\{100\}〈001〉のCube方位である。これは Hibino ら ${ }^{10)}$ が報告した部分再結晶状態の 3004 合金熱延板に $10 \%$ の軽冷間圧延を加えた場合と異なる挙動で, 引張前では $\{100\}\langle 001\rangle$ の方位密度は $13 \times$ random であったが, 引張後の Cube 方位密度は $19 \times$ random まで増加した。この $\{100\}\langle 001\rangle$ の引張变形による方位变化の挙動は, 井上ら ${ }^{11)}$ の結果と一致 した。

Fig. 7 a),b）に $0^{\circ}$ 方向に引張変形を加えた場合に最も方位 密度变化が認められた $\varphi_{2}=0^{\circ}$ 断面の ODF の解析結果を示す。 a) は $\phi=0^{\circ}, \varphi_{1}=0 \sim 45^{\circ}$, b) は $\varphi_{1}=0^{\circ}, \phi=0 \sim 45^{\circ}$ で, 公称ひず み 5 25\% まで変形を加えた場合の方位密度変化である。引
張变形を施すと（001）[100］の Cube 方位密度は变形前より 増加した。さらに, $\varphi_{1}=10^{\circ}$ までの ND Rotated Cube 方位の方 位密度も増加した。一方, $\varphi_{1}=15 \sim 25^{\circ}$ までの ND Rotated Cube の方位密度は, 変形量が大きくなるにつれてわずかなが ら低下した。Just Cube 方位を含む $\varphi_{1}=10^{\circ}$ までの ND Rotated Cube 方位 の方位密度が増加した一つの要因に, $\varphi_{1}=15 \sim 25^{\circ}$ までの ND Rotated Cube 方位が（001）[100］の方向へ方位回転 した影響が考えられる。これに対し, Just Cube 方位を含む RD Rotated Cube 方位の場合は, $\phi=20^{\circ}$ までの Cube 方位密度 が引張変形前より増加した。

Fig. 8 a）に圧延方向に対して $45^{\circ}$ 方向に引張变形を施す 前の ODF を，b）は公称ひずみ $15 \%$ まで引張变形を施した後 の ODFを示す。変形前後で大きく変化した結晶方位は 
a)

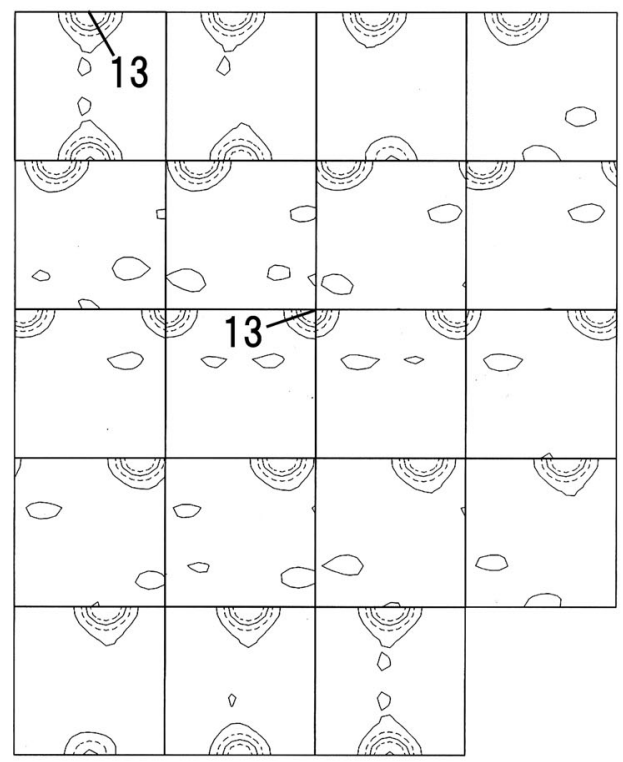

b)

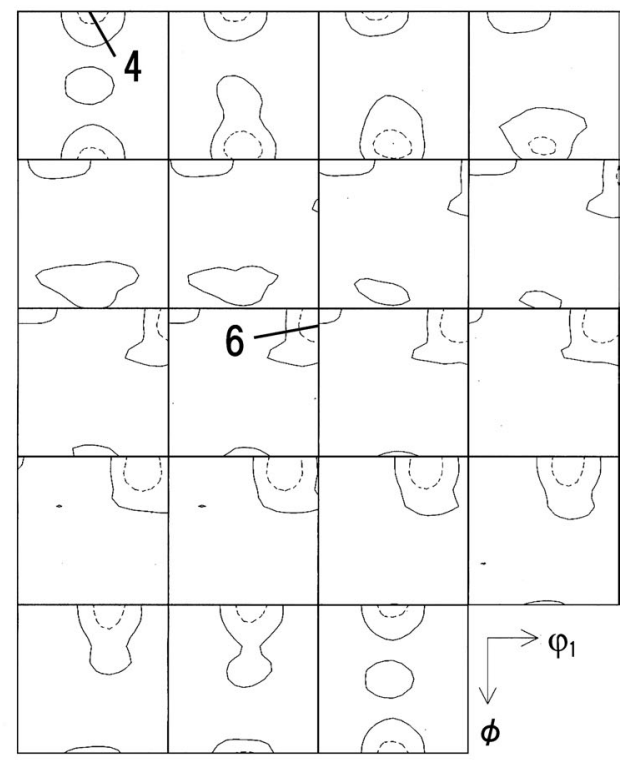

Levels:2, 4, 6, 8, 12, 16

Fig. 8 Orientation distribution functions before and after tensile deformation at $45^{\circ}$ to $\mathrm{RD}$.

a): before deformation

b): after $15 \%$ deformation

(001) [1]10］の ND Rotated Cube 方位であった。この結晶方位 の場合, 引張前では $13 \times$ random の方位密度であったが, 引張後では $4 \times$ random の方位密度まで低下した。この $\{100\}\langle 011\rangle$ の引張变形による方位変化の挙動は, 井上ら ${ }^{11)}$ の結果と一致した。さらに, TD 軸迴りに方位回転が起こ $り^{12)}$, (118) [ $\left.\overline{4} \overline{4} 1\right]$ が $6 \times$ random の最も高い方位密度に变化 した。

Fig. 9 は $45^{\circ}$ 方向に引張変形を加えた場合に最む方位密度 変化が認められた $\varphi_{2}=45^{\circ}, \varphi_{1}=90^{\circ}, \phi=0 \sim 45^{\circ}$ 断面の ODF の解 析結果を示す。变形量は公称ひずみで $5 \sim 25 \%$ である。变形 量が大きくなるにつれ，（001）[1110］の方位密度は低下した。 さらに，公称ひずみ $5 \%$ では（1110）[5 $5 \overline{5} 1]$ に近い方位が，

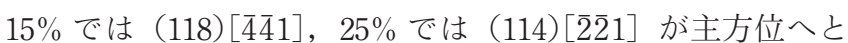
変化した。 $\{001\}\langle 110\rangle$ は变形に対して不安定であり，変形量 が大きいと $\mathrm{Cu}$ 方位まで方位回転することが報告13) されてい るが，今回の実験では $\mathrm{Cu}$ 方位までの回転は認められなかっ た。

アルミニウムの積層欠陥エネルギーは, 約 $200 \mathrm{erg} / \mathrm{cm}^{2}$ と高 く, このような積層欠陥エネルギーの高い金属は, 転位の拡 張幅が狭いため, らせん転位の交差すべりが容易に起こり塑 性緩和が生じる14)。すなわち，これは動的回復の起こりやす さを意味している。結晶方位は積層欠陥エネルギーに対し影 響を及ぼさないが，結晶方位によって活動するすべり系が異 なれば動的回復に差が生じるものと考えられる。

多結晶体の場合には結晶粒界の影響や隣接粒との方位関係 があり，完全には単結晶のようなすべり変形の挙動にならな いが，ある特定方位の集積が強い場合には，その結晶方位の 特徴が現れるむのと考えられる。たとえば，この実験で用い た供試材では主方位が $\{100\}\langle 001\rangle$ の Cube 方位であるので, $0^{\circ}$ 方向に引張変形を加えると引張軸方位の多くは〈001〉に なる。シュミット因子から活動すべり系を計算すると $-\mathrm{a} 2$,

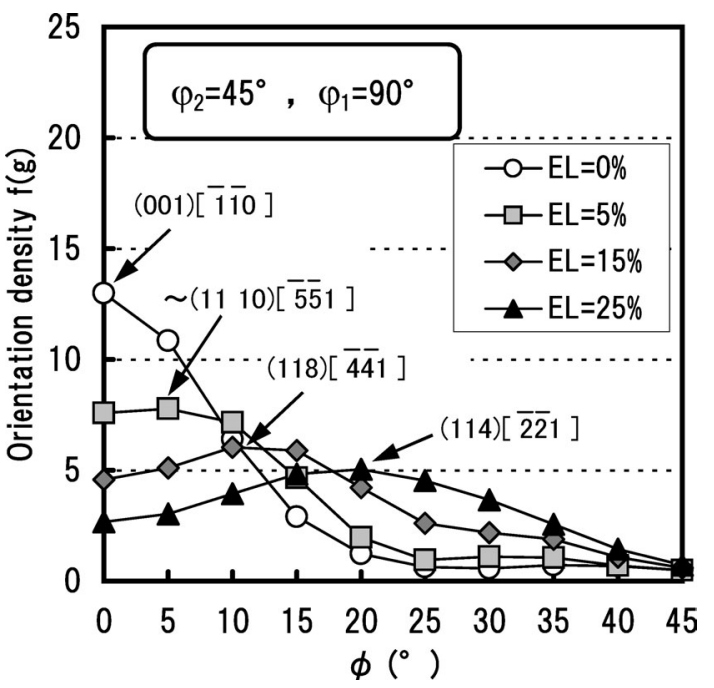

Fig. 9 Change in orientation density of $\varphi_{2}=45^{\circ}$ section by tensile deformation at $45^{\circ}$ to $\mathrm{RD}$.

a3, b2, - b3, c2, - c3, - d2, d3 の 8 つのすべり系*1 が選択され る。この中で, $-\mathrm{a} 2$ と $-\mathrm{d} 2, \mathrm{a} 3$ と $-\mathrm{b} 3, \mathrm{~b} 2$ と $\mathrm{c} 2$ および $-\mathrm{c} 3$ と d3 は交差すべり系の関係にある。一方， $45^{\circ}$ 方向に变形を加 えた場合には引張軸方位の多くは〈011〉になり，a1，-a2 ま たは b1，-b2 のすべり系が活動する可能性が考えられる。こ れらは共役すべり系の関係にある。

一般には活動すべり系の数が多いほど加工硬化が大きくな る。したがって, 変形の初期段階では $45^{\circ}$ 方向よりも $0^{\circ}$ 方向 の方が加工硬化が大きい。そのため, 加工硬化率も大きくな る。しかし, 変形量が大きくなるに従い, 転位を多く導入し た $0^{\circ}$ 方向は動的回復が起こりやすくなる。さらに, 交差す

*1 すべり系は，Bishop と Hill の表示法 ${ }^{15)}$ で表した。 
べり系の活動も重畳効果として現れると考えられる ${ }^{16)}$ 。その ため, $0^{\circ}$ 方向の加工硬化率の低下量は $45^{\circ}$ 方向よりあ大きく なり， $0^{\circ}$ 方向の伸びは $45^{\circ}$ 方向よりあ小さくなったと考えら れる。

\section{4. 結言}

純アルミニウム焼なまし板の機械的性質の異方性発生メカ ニズムを様々な観点から整理した結果，以下の結論を得た。

（1）降伏応力には異方性は認められなかったが，引張变形 時の加工硬化挙動や流動応力, さらに, 伸びの大きさは引張 方向を変えることで異方性が現れた。

（2）伸びを破断伸び，一様伸び，局部伸びに分類し，各伸 びの異方性について検討したところ, 破断伸びの異方性挙動 は一様伸びのそれとよく一致した。

（3）一様伸びの異方性は加工硬化挙動の異方性と関係があ り,これらの異方性には結晶方位の影響が大きい。しかし, 結晶方位と転位組織とは密接な関係があるので, 異方性を検 討するときには転位組織変化む合せて考慮する必要があると 考えられる。

\section{参 考 文 献}

1）林 央：塑性と加工, 44 (2003), 196-201.
2）井上博史：軽金属，42（1992），358-367.

3）佐久間尚幸，小松原俊雄，小松伸也：軽金属，52（2002），5357.

4) T. Sakuma, T. Komatsubara and S. Komatsu: Mater. Sci. Forum, 396-402, No. 2 (2002), 1055-1060.

5）佐久間尚幸，小松原俊雄：軽金属，53（2003），61-66.

6 C. Johnson and D. J. Lloyd: Mater. Sci. Forum, 331-337, No. 2 (2000), 715-726.

7）たとえば, E. Hornbogen 著, 小林俊郎, 梶野俊彦, 新家光雄 共訳：材料, 共立出版, (1989), p. 123-125.

8) R. G. O'Donnell and B. A. Parker: in Efficiency in Sheet Metal Forming, Proc. 13th Biennial Congress, IDDRG, Melbourne, (1984), 372-382.

9）吉田冬樹, 池田賢一, 中島英治, 阿部 弘：まてりあ, 40 (2001), 638-641.

10) A. Hibino, T. Sakuma and T. Komatsubara: Mater. Sci. Forum, 331337, No. 2 (2000), 775-780.

11）井上博史, 稲数直次：軽金属, 44 (1994), 97-103.

12) P. Cizek, B. P. Wynne, Hong Lu and B. A. Parker: Mater. Sci. Eng., A219 (1996), 44-55.

13） R. Becker, J. F. Butler, Jr., H. Hu and L. A. Lalli: Met. Trans. A., 22A (1991), 45-58.

14）吉永日出男, 栗下裕明：軽金属, 31 (1981), 359-368.

15） J. F. W. Bishop and R. Hill: Philos. Mag., 42 (1951), 414-427.

16) B. P. Wynne, P. Cizek, C. H. J. Davies and B. A. Parker: Proceedings of Materials 98, (1998), 627-632. 